\title{
Quantification of Ticlopidine in Human Plasma Using Protein Precipitation and Liquid Chromatography Coupled with Tandem Mass Spectrometry
}

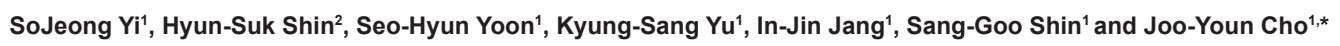

${ }^{1}$ Department of Clinical Pharmacology \& Therapeutics, Seoul National University College of Medicine and Hospital, Seoul, Republic of Korea ${ }^{2}$ Analytical Chemistry Laboratory, Clinical Research Institute, Seoul National University Hospital, Seoul, Republic of Korea

\begin{abstract}
A simple and rapid method has been developed and validated for determination of ticlopidine in human plasma using protein precipitation and liquid chromatography coupled with tandem mass spectrometry (LC/MS/MS). Ticlopidine was extracted from $20-\mu \mathrm{L}$ aliquots of human plasma by one-step protein precipitation with $980 \mu \mathrm{L}$ of acetonitrile containing $10 \mathrm{ng} / \mathrm{mL}$ clopidogrel as an internal standard (IS). Chromatographic separation was performed on a reverse-phase Gemini $C_{18}$ column $(50 \mathrm{~mm} \times 2.0 \mathrm{~mm}, 5 \mu \mathrm{m})$ with an isocratic mobile phase (acetonitrile: 1 $\mathrm{mM}$ ammonium acetate in water $=75: 25, \mathrm{v} / \mathrm{v}$ ). Ticlopidine and IS were detected and quantified by tandem mass spectrometry with positive electrospray ionization using multiple reaction monitoring of the transition $\mathrm{m} / \mathrm{z} 264.04$ to $\mathrm{m} / \mathrm{z} 154.20$ for ticlopidine and $\mathrm{m} / \mathrm{z} 322.40$ to $\mathrm{m} / \mathrm{z} 212.20$ for IS. This method was linear over the concentrations ranging from 2 to $2000 \mathrm{ng} / \mathrm{mL}$. The accuracy in the inter-batch assay was $92.4-95.6 \%$ and the precision was within $6.4 \%$ coefficient of variation. The validated method was successfully applied to the human pharmacokinetic study of ticlopidine.
\end{abstract}

Keywords: Ticlopidine; Human plasma; Protein precipitation; LC/ MS/MS; Validation

\section{Introduction}

Ticlopidine (5-[ (2-chlorophenyl) methyl] -4, 5, 6, 7 - tetrahydrothieno $[3,2-c]$ pyridine hydrochloride), an inhibitor of platelet aggregation, is used therapeutically for the prevention of stroke and myocardial infarction in high-risk patients [1-3]. Its mechanism of action involves inhibiting the binding of adenosine diphosphate (ADP) to receptor P2Y12 on the platelet membrane and modifying glycoprotein IIb/IIIa, which inhibits the binding of fibrinogen, resulting in the inhibition of platelet aggregation [4].

Several methods have been described for the quantification of ticlopidine in biological fluid, including gas chromatography coupled with mass spectrometry [5-7], high performance liquid chromatography (HPLC) with ultraviolet light [8, 9], HPLC coupled with mass spectrometry (LC/MS) $[10,11]$ and HPLC coupled with tandem mass spectrometry (HPLC/MS/MS)[12]. The previous methods using HPLC coupled with mass spectrometry employed manual solid-phase extraction (SPE) [10] or liquid-liquid extraction [11, 12]. The solidphase extraction often involves multi-step purification and evaporation, and a plasma volume of at least 0.5 to $1 \mathrm{~mL}$ plasma is usually required. The liquid-liquid extraction often needs high-purity organic solvents, is troublesome to handle, and requires an evaporation step. It can be expensive and time-consuming.

In the present study, we developed and validated a high throughput, selective HPLC/MS/MS method for the determination of ticlopidine in human plasma with a micro-sample volume using one-step protein precipitation.

\section{Experimental Procedure}

Other than the sample preparation method, we referred to the previously reported HPLC/MS/MS method by Borges et al. [12], and modified it slightly as follows.

\section{Materials}

Ticlopidine hydrochloride (Lot No. WST 06016; purity, > 98\%) was provided by Yuyu Pharma. Inc. (Seoul, Korea). (+)-Clopidogrel hydrogen sulfate (purity, > 98\%), an internal standard (IS), was purchased from Toronto Research Chemicals Inc. (North York, Canada). Ammonium acetate was purchased from Sigma-Aldrich (St. Louis, MO, USA), and HPLC grade acetonitrile and methanol were purchased from Fischer Scientific (Fair Lawn, NJ, USA). A Milli-Q (Millipore Co, Milfora, MA, USA) water purification system was used to obtain the purified water for the analysis. Blank human plasma was provided by the Blood Bank in Seoul National University Hospital and stored at approximately $-70^{\circ} \mathrm{C}$ until used.

\section{Chromatographic conditions}

A Symbiosis Pharma HPLC system (Spark Holland, Emmen, Netherlands) consisting of a binary solvent pump, degasser, and autosampler was used for setting the reverse-phase liquid chromatographic conditions. The chromatographic separation was achieved on a Gemini $\mathrm{C}_{18}$ column $(50 \times 2.0 \mathrm{~mm}, 5 \mu \mathrm{m}$; Phenomenex, Torrance, CA, USA) with a Gemini $\mathrm{C}_{18}$ guard column $(4 \times 2.0 \mathrm{~mm}$, $5 \mu \mathrm{m}$; Phenomenex) at room temperature. The isocratic mobile phase consisted of acetonitrile and $1 \mathrm{mM}$ ammonium acetate in water $(75: 25$, $\mathrm{v} / \mathrm{v}$ ) and eluted at a flow rate of $0.30 \mathrm{~mL} / \mathrm{min}$. The temperature of the autosampler was maintained at $4^{\circ} \mathrm{C}$.

${ }^{*}$ Corresponding author: Joo-Youn Cho, PhD, Department of Clinical Pharmacology \& Therapeutics, Seoul National University College of Medicine and Hospital, 101 Daehangno, Jongno-gu, Seoul, Republic of Korea, 110-744, Tel: +822-740-8286; Fax: +82-2-742-9252; E-mail: joocho@snu.ac.kr

Received January 19, 2011; Accepted February 24, 2011; Published March 07, 2011

Citation: Yi SJ, Shin HS, Yoon SH, Yu KS, Jang IJ, et al. (2011) Quantification of Ticlopidine in Human Plasma Using Protein Precipitation and Liquid Chromatography Coupled with Tandem Mass Spectrometry. J Bioanal Biomed 3 : 059-063. doi:10.4172/1948-593X.1000044

Copyright: (c) 2011 Yi SJ, et al. This is an open-access article distributed under the terms of the Creative Commons Attribution License, which permits unrestricted use, distribution, and reproduction in any medium, provided the original author and source are credited. 
Citation: Yi SJ, Shin HS, Yoon SH, Yu KS, Jang IJ, et al. (2011) Quantification of Ticlopidine in Human Plasma Using Protein Precipitation and Liquid Chromatography Coupled with Tandem Mass Spectrometry. J Bioanal Biomed 3: 059-063. doi:10.4172/1948-593X.1000044

\section{Mass spectrometric conditions}

Mass spectrometric detection employed an API 4000QTRAP (Applied Biosystems/MDS SCIEX, Foster City, CA, USA) equipped with an electrospray ionization (ESI) source operated in the positive ion mode. The curtain, nebulizer, and turbo gas (nitrogen) were set at 10 , 40 , and 50 psi, respectively. The ion spray voltage was adjusted to 5500 $\mathrm{V}$ and the source temperature was set at $600^{\circ} \mathrm{C}$. The mass spectrometer was operated in the multiple reaction monitoring (MRM) mode at unit resolution for both Q1 and Q3 with a dwell time of $200 \mathrm{~ms}$ per MRM channel. The transition of the protonated precursor to the product ion was monitored at $\mathrm{m} / \mathrm{z} 264.04$ to $\mathrm{m} / \mathrm{z} 154.20$ for ticlopidine and $\mathrm{m} / \mathrm{z}$ 322.40 to $\mathrm{m} / \mathrm{z} 212.20$ for clopidogrel. Declustering potentials were set at 71 and $40 \mathrm{eV}$ for ticlopidine and clopidogrel, respectively, and collision energies were set at 25 and $23 \mathrm{eV}$, respectively. Data acquisition and integration were processed by Analyst version 1.4.1 software (Applied Biosystems).

\section{Preparation of calibration standards and quality control samples}

Stock solutions of ticlopidine and clopidogrel (IS) were prepared by dissolving $1 \mathrm{mg} / \mathrm{mL}$ in methanol-water solution $(50: 50, \mathrm{v} / \mathrm{v})$ and stored at $4^{\circ} \mathrm{C}$. Ticlopidine stock solution was diluted serially with $50 \%$ methanol to obtain working standard solutions $(0.04,0.1,0.4,1$, $4,10,40,100 \mu \mathrm{g} / \mathrm{mL})$. To prepare calibration standards, $50 \mu \mathrm{L}$ of each working standard solution was spiked to $950 \mu \mathrm{L}$ of blank human plasma, yielding final concentrations of 2, 5, 20, 50, 200, 500, and $2000 \mathrm{ng} / \mathrm{mL}$. The concentrations of ticlopidine and clopidogrel were calculated in the salt free form. The lower limit of quantification (LLOQ, $2 \mathrm{ng} / \mathrm{mL}$ ) for ticlopidine in human plasma was defined as the lowest concentration with a signal-to-noise ratio over 10 and acceptable accuracy (80-120\%) and precision $(<20 \%)$.

Quality control (QC) samples at low, medium, and high concentration $(6,100$, and $1600 \mathrm{ng} / \mathrm{mL}$, respectively) were prepared by spiking the working standard solutions of ticlopidine into blank human plasma, and aliquots $(100 \mu \mathrm{L})$ were stored in the freezer below $-70^{\circ} \mathrm{C}$ until analysis. The IS stock solution was diluted with acetonitrile to a final concentration of $10 \mathrm{ng} / \mathrm{mL}$. The calibration standards and QC samples were extracted for each analytical batch with the unknown samples.

\section{Sample preparation}

All frozen human plasma samples were thawed at room temperature. Twenty microliters of each unknown samples, standards and QC samples were transferred to $1.5 \mathrm{~mL}$ micro-centrifuge tubes, and $980 \mu \mathrm{L}$ of acetonitrile containing IS $(10 \mathrm{ng} / \mathrm{mL})$ were added. For the blank sample, $20 \mu \mathrm{L}$ of blank plasma was pipetted to $980 \mu \mathrm{L}$ of $100 \%$ acetonitrile. Then, the tubes were vortexed for $1 \mathrm{~min}$ and followed by centrifugation at $4^{\circ} \mathrm{C}, 13,000 \mathrm{rpm}$ for $5 \mathrm{~min}$ to the precipitate protein. A $200-\mu \mathrm{L}$ aliquot of each supernatant was transferred into the injection vial and a $2-\mu \mathrm{L}$ aliquot was injected into the LC/MS/MS system. All prepared samples were kept at $4^{\circ} \mathrm{C}$ until injection.

\section{Method validation}

Stability: The stability of ticlopidine in human plasma was evaluated using six replicates of low and high QC samples under three different test conditions as follows. For the short-term stability test, QC samples were kept at room temperature for $18 \mathrm{~h}$ before analysis. For the freeze-thaw stability test, QC samples were analyzed after 3 successive freeze-thaw cycles. The post-preparative stability was assessed using the processed QC samples which were kept at $4^{\circ} \mathrm{C}$ on the autosampler for $36 \mathrm{~h}$ before analysis.

Selectivity, carryover and linearity: Selectivity was investigated by comparing six blank plasma samples from different origins with the plasma spiked with ticlopidine (at LLOQ) and IS. The carryover effect on the LC/MS/MS system was evaluated by injecting consecutively blank samples after a standard sample at the highest concentration of the calibration range.

A calibration curve was prepared by 7 standard samples covering the entire range of 2-2000 $\mathrm{ng} / \mathrm{mL}$ of ticlopidine. The linearity of each calibration curve was assessed by a weighted $\left(1 / \mathrm{x}^{2}\right)$ linear regression method based on the peak area ratios (y) of ticlopidine to IS versus the nominal concentration $(\mathrm{x})$ of ticlopidine.

Precision, accuracy and recovery: The intra-batch precision and accuracy were assessed using 6 replicates at three different concentrations $(6,100$ and $1600 \mathrm{ng} / \mathrm{mL})$ within a batch. The interbatch precision and accuracy were determined using 6 replicates of three different concentration levels on 5 different days. Precision was expressed as relative standard deviation, RSD $(\%)=100 \times($ standard deviation/mean) and accuracy was calculated as accuracy $(\%)=100$ $\times$ (mean observed concentration/spiked concentration). Recovery was calculated by comparing mean peak areas obtained from extraction of QC samples and extracted blank plasma spiked with the corresponding concentration of ticlopidine.

\section{Results}

\section{Mass spectrometry and chromatography}

Mass spectra of ticlopidine and clopidogrel (IS) in the positive ion mode showed the protonated molecular ions $[\mathrm{M}+\mathrm{H}]^{+}$as the major ion

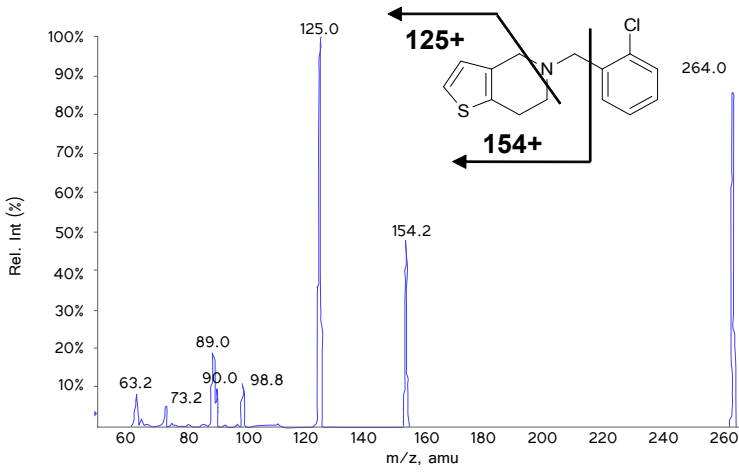

(B)

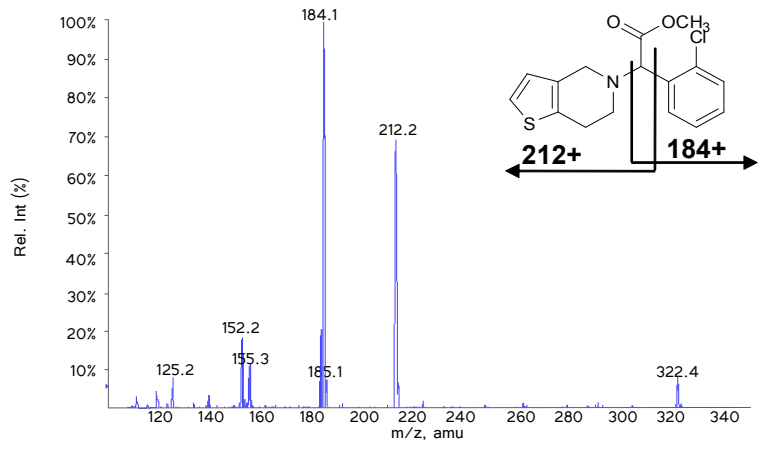

Figure 1: Product ion mass spectra of ticlopidine (A) and clopidogrel (IS) (B) in positive ion mode. Major product ions from MS/MS fragmentation were interpreted in the inlaid structural diagrams. 
Citation: Yi SJ, Shin HS, Yoon SH, Yu KS, Jang IJ, et al. (2011) Quantification of Ticlopidine in Human Plasma Using Protein Precipitation and Liquid Chromatography Coupled with Tandem Mass Spectrometry. J Bioanal Biomed 3: 059-063. doi:10.4172/1948-593X.1000044

species, $\mathrm{m} / \mathrm{z} 264.04$ and 322.40 , respectively. The chemical structures of ticlopidine and clopidogrel with proposed fragmentation patterns are shown in Figure 1 based on the full-scan product ion spectra of $[\mathrm{M}+\mathrm{H}]^{+}$ ions. The MS/MS parameters were optimized to maximize the response for precursor to product ion in the positive ion mode. Consequently, the mass transition was monitored at $\mathrm{m} / \mathrm{z} 264.04$ to 154.20 for the analyte and $\mathrm{m} / \mathrm{z} 322.40$ to 212.20 for IS. The MRM ion chromatograms were obtained after simple preparation of human plasma samples with acetonitrile showed that total chromatographic run time was $5.0 \mathrm{~min}$ and retention times were $2.1 \mathrm{~min}$ for ticlopidine and $1.6 \mathrm{~min}$ for IS (Figure 2).

\section{Selectivity, carryover and linearity}

No interfering peaks at the elution times for the analyte or IS were observed in the six blank human plasma samples from different origins. Figure 2 shows typical chromatograms for blank plasma, blank plasma with IS, plasma spiked with ticlopidine at $2 \mathrm{ng} / \mathrm{mL}$ (LLOQ), and
(A)

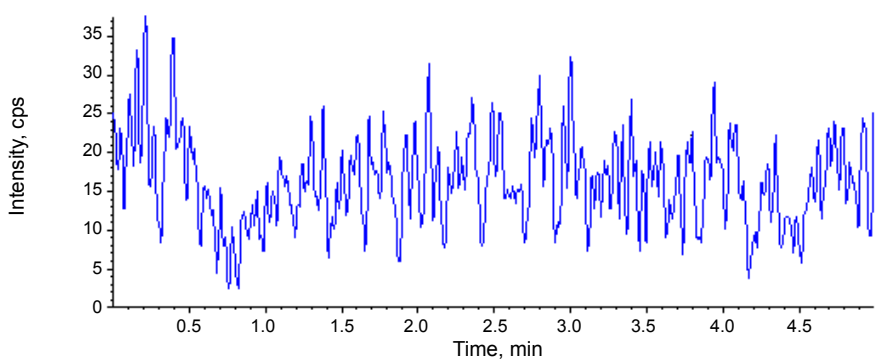

(B)

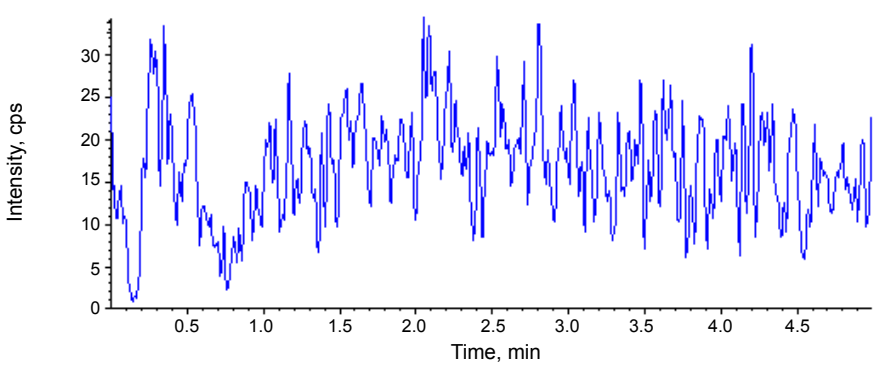

(C)

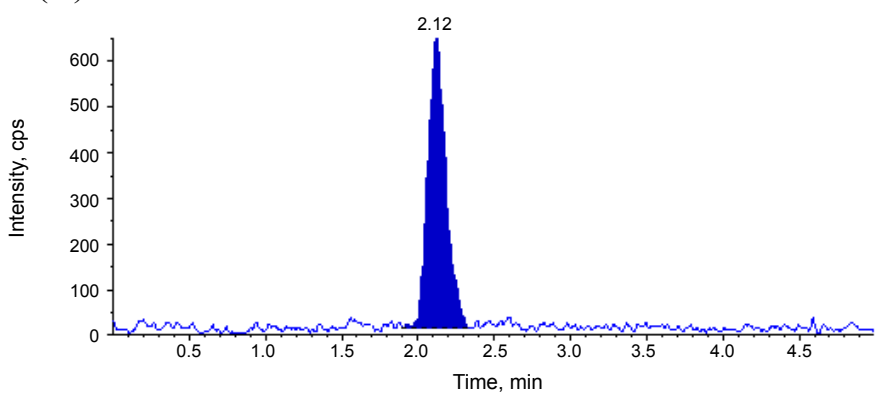

(D)

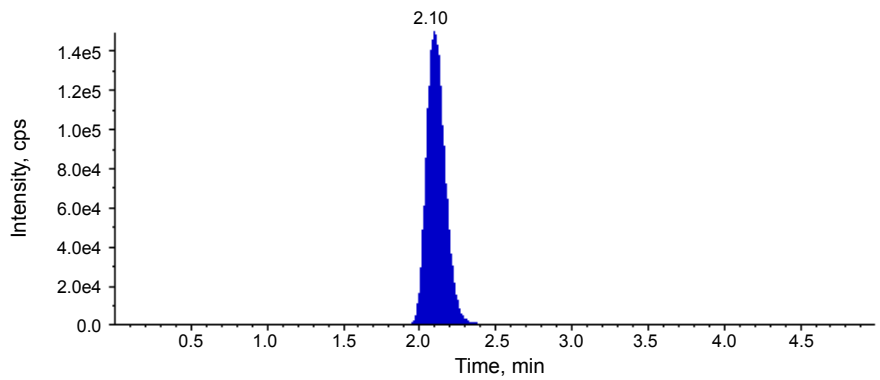

Clopidogrel (IS)
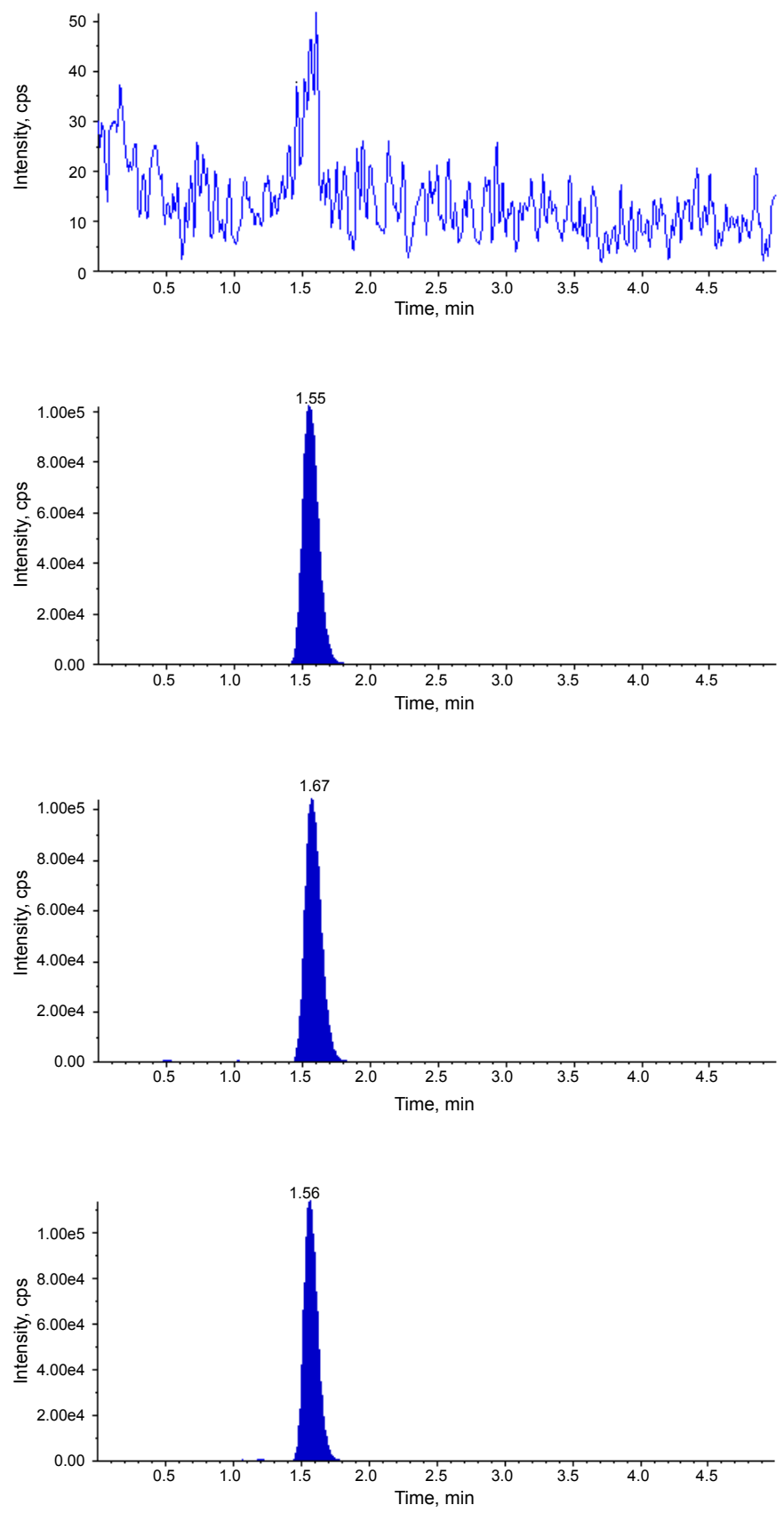

Figure 2: MRM ion chromatogram of ticlopidine (m/z 264.04 to $\mathrm{m} / \mathrm{z} 154.20)$ and clopidogrel (IS, $\mathrm{m} / \mathrm{z} 322.40$ to 212.20 ) in (A) a blank plasma sample, (B) a zero sample, (C) a LLOQ $(2 \mathrm{ng} / \mathrm{mL})$ sample, and (D) a plasma sample from a healthy volunteer at 1.5 hours after oral administration of ticlopidine $250 \mathrm{mg}$. 
plasma obtained from a volunteer at 1.5 hours after oral administration of ticlopidine $250 \mathrm{mg}$. LLOQ of ticlopidine was $2 \mathrm{ng} / \mathrm{mL}$, using 20 $\mu \mathrm{L}$ of human plasma. There was no carryover effect observed; no enhancement in the response was observed in the chromatogram of a blank sample after subsequent injection of the highest calibration standard at the retention time of analyte and IS (data not shown). The calibration curves for ticlopidine were established in the range of 2-2000 $\mathrm{ng} / \mathrm{mL}$ and exhibited good linearity with the correlation coefficients ( $\mathrm{r}$ ) ranging between 0.9979 and 0.9999 in five batches.

\section{Precision, accuracy and recovery}

The precision and accuracy of the calibration curves ranged 1.0 $3.7 \%$ and $95.5-103.2 \%$, respectively. The intra- and inter-batch precision of this method was below 2.1 and $6.4 \%$, respectively, and the intra- and inter-batch accuracy was $101.0-102.9 \%$ and $92.4-95.6 \%$, respectively (Table 1).

The mean recovery of ticlopidine at the 6,100 , and $1600 \mathrm{ng} / \mathrm{mL}$ levels were $102.7 \%, 100.8 \%$, and $100.7 \%$, respectively. The recovery of IS at the concentration of $10 \mathrm{ng} / \mathrm{mL}$ was $84.0 \%$.

\section{Stability}

The stability of ticlopidine in human plasma under various conditions is shown in Table 2. Ticlopidine was stable after short-term storage at room temperature for $18 \mathrm{~h}$, three freeze-thaw cycles, or storage in an autosampler at $4^{\circ} \mathrm{C}$ for $36 \mathrm{hr}$, with a difference of less than $5.4 \%$ between the reference and test concentrations observed. The longterm stability test was not performed because Borges et al. reported that ticlopidine in human plasma was stable for 269 days at $-20^{\circ} \mathrm{C}$ [12].

\section{Application of the method to human pharmacokinetic study}

This simple and rapid method for determination of ticlopidine in human plasma was successfully applied to a single dose pharmacokinetic study after oral coadministration of ticlopidine $250 \mathrm{mg}$ in 24 healthy male volunteers [13]. Blood samples $(8 \mathrm{~mL})$ were withdrawn in a

\begin{tabular}{|c|c|c|c|c|}
\hline \multirow{2}{*}{$\begin{array}{c}\text { Nominal } \\
\begin{array}{c}\text { concentration } \\
(\mathrm{ng} / \mathrm{mL})\end{array}\end{array}$} & \multicolumn{2}{|c|}{ Intra-batch $(\mathrm{n}=6)$} & \multicolumn{2}{|c|}{ Inter-batch $(\mathrm{n}=5)$} \\
\cline { 2 - 5 } & $\begin{array}{c}\text { Precision } \\
(\text { RSD \%) }\end{array}$ & $\begin{array}{c}\text { Accuracy } \\
(\%)\end{array}$ & $\begin{array}{c}\text { Precision } \\
(\text { RSD \%) }\end{array}$ & $\begin{array}{c}\text { Accuracy } \\
(\%)\end{array}$ \\
\hline 6 & 2.1 & 102.9 & 6.4 & 95.6 \\
\hline 100 & 1.6 & 101.0 & 5.4 & 94.0 \\
\hline 1600 & 0.6 & 101.5 & 6.0 & 92.4 \\
\hline
\end{tabular}

Table 1: Precision and accuracy for ticlopidine in human plasma.

\begin{tabular}{|c|c|c|c|c|}
\hline \multirow[b]{2}{*}{ Conditions } & \multirow{2}{*}{$\begin{array}{c}\text { Nominal } \\
\text { concentration } \\
(\mathrm{ng} / \mathrm{mL})\end{array}$} & \multicolumn{2}{|c|}{$\begin{array}{l}\text { Observed concentration } \\
(\mathrm{ng} / \mathrm{mL})\end{array}$} & \multirow{2}{*}{$\begin{array}{c}\text { Difference } \\
(\%) \\
\text { between } \\
\text { reference } \\
\text { and test }\end{array}$} \\
\hline & & $\begin{array}{c}\text { Mean of } \\
\text { reference }(n=6)\end{array}$ & $\begin{array}{c}\text { Mean of } \\
\text { test } \\
(n=6)\end{array}$ & \\
\hline \multirow{2}{*}{$\begin{array}{l}\text { Storage of samples at } \\
\text { room temperature for } \\
18 \mathrm{hr}\end{array}$} & 6 & 5.5 & 5.2 & -5.4 \\
\hline & 1600 & 1430.7 & 1363.0 & -4.7 \\
\hline \multirow{2}{*}{$\begin{array}{c}\text { Three freeze-thaw } \\
\text { cycles } \\
\left(-70^{\circ} \mathrm{C}\right)\end{array}$} & 6 & 6.0 & 5.8 & -3.3 \\
\hline & 1600 & 1500.8 & 1491.0 & -0.7 \\
\hline \multirow{2}{*}{$\begin{array}{l}\text { Storage of extracted } \\
\text { samples } \\
\text { in autosampler at } 4^{\circ} \mathrm{C} \\
\text { for } 36 \mathrm{hr}\end{array}$} & 6 & 6.2 & 6.3 & 1.6 \\
\hline & 1600 & 1624.3 & 1612.0 & -0.8 \\
\hline
\end{tabular}

Table 2: Stability of ticlopidine in human plasma under various conditions. heparinized tube before dosing and at $0.5,1,1.5,2,2.5,3,4,6,8,12$, 24, and 48 hours after administration of ticlopidine $250 \mathrm{mg}$. Plasma was separated within $30 \mathrm{~min}$ after blood sampling by centrifugation at $4^{\circ} \mathrm{C}$ and $3,000 \mathrm{rpm}$ for $10 \mathrm{~min}$, and stored below $-70^{\circ} \mathrm{C}$ until analysis. The LLOQ $(2 \mathrm{ng} / \mathrm{mL})$ of the assay has sufficient reliability to allow pharmacokinetic parameters of ticlopidine, given in therapeutic doses ( $250 \mathrm{mg}$ ), to be calculated. A representative chromatogram of a plasma sample obtained at $1.5 \mathrm{~h}$ from a subject who had administered a single oral dose of ticlopidine $250 \mathrm{mg}$ is shown in Figure 2 (D) and the sample concentration was determined to be $569.4 \mathrm{ng} / \mathrm{mL}$ for ticlopidine. The mean plasma concentration-time profiles of 24 healthy volunteers are shown in the supplementary figure. The maximum ticlopidine concentrations in plasma $\left(\mathrm{C}_{\max }\right)$ values and the times taken to reach $\mathrm{C}_{\max }\left(\mathrm{T}_{\max }\right)$ after dosing were consistent with those of the literature [14, 15].

\section{Discussion}

In this study, we developed a simple and rapid one-step method of protein precipitation to determine ticlopidine concentration in human plasma. Validation results of method indicate that this HPLC/ MS/MS allows sensitive, selective, and high throughput quantification of ticlopidine so that it is considered suitable for the clinical pharmacokinetic studies of ticlopidine. It avoids the use of complicated and expensive manual solid phase extraction techniques and timeconsuming liquid-liquid solvent extraction with evaporation that was used in previously reported procedures. In addition, this method requires only a small volume of plasma sample $(20 \mu \mathrm{L}$ compared with $500 \mu \mathrm{L}$ for a solid phase extraction [10] and $200-500 \mu \mathrm{L}$ for a liquidliquid extraction [11,12].

Compared to the previously reported HPLC/MS/MS method using liquid-liquid extraction by Borges et al., the LLOQ was slightly higher $(2.0 \mathrm{ng} / \mathrm{mL}$ versus $1.0 \mathrm{ng} / \mathrm{mL})$, and the run time was longer $(5$ min versus $3 \mathrm{~min}$ ). However, the recovery of protein precipitation was almost $100 \%$ compared with $85.0 \%-91.8 \%$ for liquid-liquid extraction. Accuracy and precision were comparable with the previous study: intra- and inter-day accuracies were $101.0-102.9 \%$ and $92.4 \%-95.6 \%$ in this study, and $105.3 \%-111.3 \%$ and $101.8 \%-105.3 \%$ in the previous study, respectively; intra- and inter-day precision variations (CV\%) were lower than $2.1 \%$ and $6.4 \%$ in this study, and $2.4 \%$ and $4.8 \%$ in the previous study, respectively. Moreover, in the previous study by Borges et al., short-term stability at room temperature for $8 \mathrm{~h}$ and autosampler stability at $12^{\circ} \mathrm{C}$ for $24 \mathrm{~h}$ were guaranteed, while those were established in this study for $18 \mathrm{~h}$ at room temperature and $36 \mathrm{~h}$ at $4^{\circ} \mathrm{C}$, respectively.

\section{Conclusion}

In conclusion, we report the development and validation of a rapid LC/MS/MS method with a simple preparation of samples for the determination of ticlopidine in human plasma over a concentration range of $2-2000 \mathrm{ng} / \mathrm{mL}$ using $20 \mu \mathrm{L}$ of plasma sample. This method showed excellent accuracy, precision, and stability. The developed method was successfully applied to the human pharmacokinetic study of ticlopidine.

\section{Acknowledgments}

This study was sponsored by Yuyu Pharma. Inc., Seoul, Republic of Korea. None of the authors have any conflicts of interest to disclose.

\section{References}

1. Noble S, Goa KL (1996) Ticlopidine. A review of its pharmacology, clinical efficacy and tolerability in the prevention of cerebral ischaemia and stroke. Drugs Aging 8: 214-232. 
Citation: Yi SJ, Shin HS, Yoon SH, Yu KS, Jang IJ, et al. (2011) Quantification of Ticlopidine in Human Plasma Using Protein Precipitation and Liquid Chromatography Coupled with Tandem Mass Spectrometry. J Bioanal Biomed 3: 059-063. doi:10.4172/1948-593X.1000044

2. Juergens CP, Wong AM, Leung DY, Lowe HC, Lo S, et al. (2004) A randomized comparison of clopidogrel and aspirin versus ticlopidine and aspirin after coronary stent implantation. Am Heart J 147: E15.

3. Müller C, Büttner HJ, Petersen J, Roskamm H (2000)A randomized comparison of clopidogrel and aspirin versus ticlopidine and aspirin after the placement of coronary-artery stents. Circulation 101: 590-593.

4. McTavish D, Faulds D, Goa KL (1990) Ticlopidine. An updated review of its pharmacology and therapeutic use in platelet-dependent disorders. Drugs 40: 238-259.

5. DiPerri T, Pasini FL, Frigerio C, Blardi P, Centini F, et al. (1991) Pharmacodynamics of ticlopidine in man in relation to plasma and blood cell concentration. Eur J Clin Pharmacol 41: 429-434.

6. Arnoux P, Sales Y, Mandray M, Lechat P, Berger Y, et al. (1991) Quantitative high-performance liquid chromatographic, gas chromatographic, and gas chromatographic-mass spectrometric analysis of ticlopidine in baboon plasma after solid-phase extraction. J Pharm Sci 80: 1092-1095.

7. Barroso M, Gallardo E, Margalho C, Monsanto P, Vieira DN (2006) Analytical approach to determine ticlopidine in post-mortem blood. Forensic Sci Int 162: 121-125

8. Furlan G, Malusà N, Strohmayer A, Klugmann FB, Decorti G, et al. (1996) Optimised method for determination of ticlopidine in serum by high performance liquid chromatography. Farmaco 51: 747-751.

9. Róna K, Ary K, Gachályi B, Klebovich I (1997) Liquid chromatographic method for the determination of ticlopidine in human plasma. J Chromatogr B Biomed Sci Appl 693: 393-398.
10. Aldo Laganà Giovanni Bellagamba, Giuseppe D'Ascenzo, Alessandra Gentili, Aldo Marino (1997) Evaluation of ticlopidine in human serum and plaque by liquid chromatography/atmospheric pressure chemical ionization mass spectrometry. Analytica Chimica Acta 354: 87-95.

11. Sun J, Jiao H, Tian Y, Zhang Z, Chen Y (2009) Quantitative determination of ticlopidine hydrochloride in human plasma by high-performance liquid chromatography-electronspray ionization mass spectrometry. Arzneimittelforschung 59: 121-128.

12. Borges NC, Mendes GD, Borges A, Oliveira SE, Barrientos-Astigarraga RE, et al. (2004) Ticlopidine quantification in human plasma by high-performance liquid chromatography coupled to electrospray tandem mass spectrometry Application to bioequivalence study. J Mass Spectrom 39: 1562-1569.

13. Kim TE, Kim BH, Kim J, Kim KP, Yi S, et al. (2009) Comparison of the pharmacokinetics of ticlopidine between administration of a combined fixeddose tablet formulation of ticlopidine $250 \mathrm{mg} /$ ginkgo extract $80 \mathrm{mg}$, and concomitant administration of ticlopidine $250-\mathrm{mg}$ and ginkgo extract $80-\mathrm{mg}$ tablets: an open-label, two-treatment, single-dose, randomized-sequence crossover study in healthy Korean male volunteers. Clin Ther 31: 2249-2257.

14. Marzo A, Dal Bo L, Rusca A, Zini P (2002) Bioequivalence of ticlopidine hydrochloride administered in single dose to healthy volunteers. Pharmacol Res 46: 401-407.

15. Lu WJ, Huang JD, Lai ML (2006) The effects of ergoloid mesylates and ginkgo biloba on the pharmacokinetics of ticlopidine. J Clin Pharmacol 46: 628-634. 